Tourism and Hospitality Research

\title{
The consequences of natural disasters in touristic destinations: The case of Madeira Island - Portugal
}

12(1) 50-56

(C) The Author(s) 2011

Reprints and permissions:

sagepub.co.uk/journalsPermissions.nav

DOI: $10.1177 / 1467358411429636$

thr.sagepub.com

\section{Luiz Pinto Machado}

Technical University of Lisbon, Portugal and UECE (Research Unit on Complexity and Economics), Portugal

\begin{abstract}
Today, destinations are evaluated by tourists according to safety and risk factors with regard to natural, terrorism and political problems. The portrayal of places in news reports can alter an area's image dramatically, even in a short period of time. Often, natural disasters have impacts on the image of international destinations that endure for months if not years. Hence, media coverage of disasters or crises is of particular concern to destinations where such disasters occur. The Island of Madeira was not prepared for a catastrophe such as the one that occurred in February 2010, and its consequence has been a huge drop in the tourism industry. Driven by the generally accepted importance of destination image as a concept to destination marketers and academics, this article proposes that previous destination image research has tended to underestimate the importance of safety, security and risk. It also proposes a strategic approach to Destination management from proactive pre-crisis planning through to strategic implementation and finally evaluation and feedback.
\end{abstract}

\section{Keywords}

crisis in Madeira, managing crisis, place marketing, place image, safety and security crisis

\section{Introduction}

Everyday, the media is full of negative reports from all over the world. Natural disasters have become so commonplace that they hardly receive passing notice on the news unless there have been a large number of casualties. Volcanoes, mudslides, tsunamis and floods are just a few of the ways nature strikes on a daily basis, leaving behind destruction and heartache. Humans have learned to prepare for the possibility of tornadoes, earthquakes, hurricanes and wildfires, but no amount of preparation can reduce the impact that natural disasters have on every aspect of society. While the visible effects of natural disasters are immediate and strongly felt, related communities can be directly/indirectly affected by them as well.

Whether the incidence of disasters or crises, both natural and man-made, is increasing, or it is simply a matter of each disaster having more devastating effects, it is apparent that people have become more concerned about their physical safety, wherever they live or travel, in a more complex, interconnected world in which adverse events in one region tend to generate shock waves globally (Grainger and Crouch, 2006). This has contributed to making us more crisis or disaster prone, aware and concerned (Richardson, 1994). These dramatic negative events can threaten, weaken or destroy the competitive advantage of a tourism destination (Ritchie and Crouch, 2003). The decade of

\section{Corresponding author:}

Luiz Pinto Machado, Instituto Superior de Economia e Gestão, Technical University of Lisbon, Rua Miguel Lupi, 20, 1249-078, Lisbon, Portugal and UECE (Research Unit on Complexity and Economics), Portugal

Email: luizpintomachadodgmail.com 


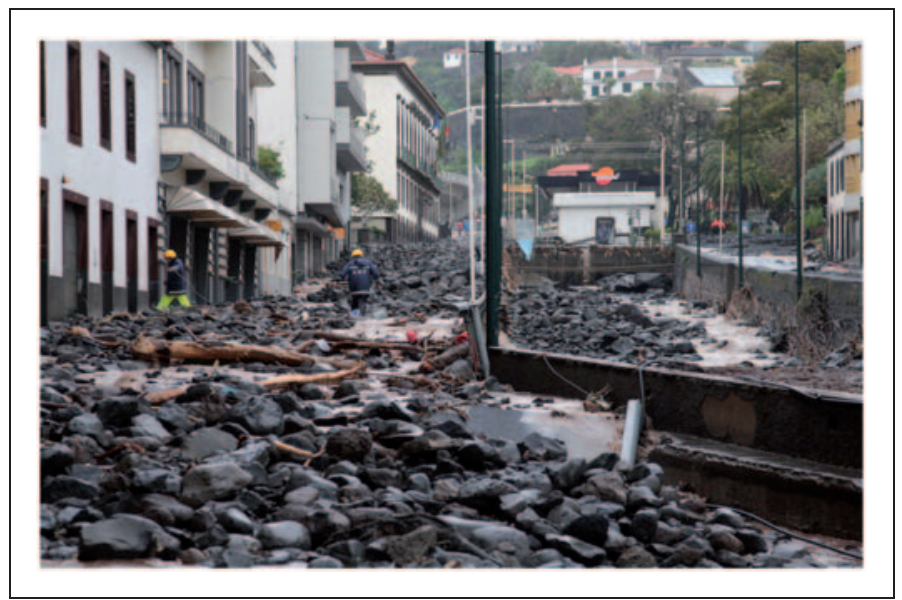

Figure 1. Funchal downtown on February 20, 2010.

2000 can be remembered for the multiplicity of negative events including natural disasters, terrorist attacks and bird flu that have severely impacted tourist destinations. Sobering for all tourism industry investors, practitioners and consumers is the increasing realization that the continued health and prosperity of the global tourism industry is indisputably correlated to the success of global safety and security initiatives (Hall et al., 2004). Despite this, relatively little research has been carried out on the disaster phenomena in tourism (Faulkner, 2001). However, as a result of the events of the last decade, the tourism industry has realized the growing importance of managing crises and disasters, which have given rise to literature and studies in this field, aimed at the tourism industry. The industry has evolved from a static approach that focused on the nature of the crises to one that allows it to be proactive in its management of disaster incidents.

In February 2010, a raging torrent of water and mud swept away people, houses and vehicles on the steep-sloped Atlantic Ocean Island with 1,1 billion Euros estimated losses. Locals said the storm was the worst in living memory. Meteorologists confirmed that the amount of rainfall that fell in 1 day on Saturday 21 st exceeded the monthly average, and one of the consequences has been a huge drop in tourism industry.

The possibility of repeat or frequent events of possibly greater magnitude and power serve to put coastal tourism destinations in an almost constant state of alert. It is noted that although crises and disasters cannot be stopped, their impacts can be limited by both public and private sector managers.

This paper concludes that the understanding and subsequent management of such incidents can be vastly improved through the extension and application of crisis and disaster management theory.

\section{Background}

The Archipelago, discovered by the Portuguese in 1418, is made up of the islands of Madeira, Porto Santo and the uninhabited islands of Selvagens and Desertas, situated between latitudes $35^{\circ}$ and $45^{\circ}$ north and longitude $17^{\circ}$ west, 620 miles $(1000 \mathrm{~km})$ from the coast of Portugal, the country to which it belongs, and 310 miles $(500 \mathrm{~km})$ from the African coast.

Madeira Island is often described as a 'floating garden', a description that reflects centuries of cultivation. The rich volcanic soil, the privileged geographical position and mountainous relief, have a surprisingly mild climate, and abundant rainfall have created contrasting landscapes: Lush River valleys, terraced hillsides planted with vines and bananas and dense primeval forest. Madeira Island has a surface area of 459 square miles $\left(741 \mathrm{~km}^{2}, 35\right.$ miles long and 13 miles wide), with its highest point being Pico Ruivo, with an altitude of 1861 meters. These islands, because of very mild average temperatures of $22^{\circ} \mathrm{C}$ in the summer and $16^{\circ} \mathrm{C}$ in the winter, and a moderate level of humidity, confer upon these islands exceptional subtropical features. The seawater temperature is also very mild, because of the influence of the warm Gulf current, presenting averages of $22^{\circ} \mathrm{C}$ in the summer and $18^{\circ}$ in the winter. The island's high quality natural habitats have been classified as a Biogenetic Reserve with flora and fauna species unique in the world, as well as subtropical and tropical fruits and vineyards that produce the famous Madeira wine. Madeira offers great trekking and walking opportunities to the many tourists who visit the island, in addition to mountaineering, game fishing, sailing and surfing, (Oliveira and Pereira, 2008). These are factors that contribute to Madeira being one of the traditional and oldest 
Table 1. Madeira island main tourism indicators, between 2000 and 2010 (*Jan/Out)

\begin{tabular}{lllllll}
\hline Tourism Indicators & 2000 & 2007 & 2008 & 2009 & $2010 *$ & \multicolumn{1}{c}{ 10/09 } \\
\hline Total beds available & 21279 & 29661 & 30580 & 31213 & 28810 & $-7.6 \%$ \\
Total guests & 740826 & 967134 & 1013281 & 911345 & $-7.8 \%$ \\
Total overnights & 4972470 & 5990015 & 6208144 & 5496696 & 4397000 & $-9.1 \%$ \\
Average length of stay & 6.7 & 5.3 & 5.3 & 5.2 & 5.8 & $11 \%$ \\
Bed occupancy rate & 59.7 & 60.1 & 60,40 & 52,10 & $50.4 \%$ & $-6.3 \%$ \\
Revpar & 32.03378 & 35.57 & 36,76 & 30,62 & 28.52 & $-11.3 \%$ \\
British guests & 168012 & 188843 & 238616 & 159176 & nd & nd \\
German guests & 136835 & 174023 & 164570 & 148536 & -11.8 \\
\hline
\end{tabular}

Source: Madeira Tourism Statistics Bureau and Direcção Regional de Estatística.

tourism destinations in the world, since the late nineteenth century. The first tourists were wealthy British visitors travelling aboard transatlantic liners and cargo ships that stopped in Funchal's port-of-call, Madeira's capital city.

The island remained the exclusive reserve of wellto-do tourists until the opening of the Funchal airport in 1963, which was to lead to the development and expansion of infrastructure and the construction of more hotels. Hotel construction increased significantly after the Portuguese Revolution in 1974. Today, Madeira has approximately 29,000 hotel beds. Visitors can choose from a wide range of accommodation options including the island's time-honoured traditional hotels, more modern forms of tourism accommodation and smaller lodging units in rural areas where tourists can come into closer contact with nature and the local people. All Madeira's hotels are famous for their hospitality, personalized service, good taste and quality Barros CP and Machado LP (2010).

While most tourists today arrive by air, Funchal is a port of call throughout the year on the itineraries of many European and transatlantic cruises. In 2009, a total of 277 ships and 436,000 passengers disembarked in Funchal, representing almost $37 \%$ of arrivals by air.

The destination is particularly popular among British, German and Scandinavian tourists between October and the spring. The peaks of tourists' arrivals happen in March and April, when the famous Flower Festival takes place. The summer season tends to attract more visitors from southern Europe, who seek an escape to Madeira's less intense heat and more peaceful atmosphere. New Year's Eve is also a peak period, with a famous firework display over Funchal that is claimed to be the largest in the world Barros CP and Machado LP (2010).

However, Table 1 shows that the tourist's figures exhibit a decreasing trend during the period under recent year's analysis (with the exception of 2008, which was a magnificent year for tourism worldwide). This raises concerns over the long-term competitive position of Madeira. It is clear that issues related to the H1N1 and economic crisis had an effect on international breaks recorded in 2009, but political and strategic factors influenced the decline. While the tourist year of 2010 clearly shows a recovery of the sector, Madeira had one of the worst years ever, due particularly to the storm of February 2010. The torrents of water and mud in that month swept away people, houses, bridges and vehicles, burying some houses under tons of mud. About 120 people were injured, 48 died and 300 spent days in temporary shelters. Some 600 lost their homes. Locals said the storm was the worst in living memory. Meteorologists said the amount of rainfall that fell in one day exceeded the monthly average. Emergency crews in more than 400 vehicles including bulldozers worked through night and day to clear tons of caked mud, boulders and snapped trees that had piled up in the capital of Funchal and other coastal communities. Parts of downtown Funchal were cordoned off as crew's pumped rainwater and sludge out of a shopping centre's underground car park where officials feared more bodies would be found. Miguel Albuquerque, the mayor of Madeira's capital Funchal, said some areas above the city were particularly badly hit, likening the scene to Dante's Inferno. Many roads in Madeira were partially destroyed or blocked with rocks, trees and mud. It took civil protection services more than $24 \mathrm{~h}$ to reach the village of Curral das Freiras, which had been cut off. Officials said one person had been killed and one was missing there.

The gravity of the crisis was reflected in hotel occupancy figures. On the same day of 20 February, almost all hotels received booking cancellations. In the following days, thousands of cancellations were received in succession and reduced the arrival of new bookings. Cruise ships scheduled to call in at one of the most 
popular spots on their itinerary were urged to find alternative destinations because 90 per cent of excursions usually offered on the island were currently impossible and unlikely to be resumed for several weeks.

An analysis of the results presented in Table 1 reveals a clear and worrying decline: Tourist arrivals, the Bed Occupancy Rate and REVPAR are 20\% lower than at the beginning of the decade, revenues have fallen by $12.5 \%$, and unemployment in that sector increased by $7 \%$ year on year in 2010 .

During the crisis, the media reports on the flooding served to damage the tourism image of Madeira Island. Isolated and localized events that occurred on the island were falsely assumed to have been widely distributed throughout the entire island. The problems were in fact contained to the immediate surrounds of the water courses that rose up from being dry or narrow channels bringing water off the mountains. In an attempt to mitigate the impact of the disaster, the local government said there had been 'no serious incident' involving the tourism sector on the island, but without effect. The withdrawal of tourists resulted in some tour operators immediately stopping the promotion and sale of holidays to Madeira Island, and led to the sudden halt of inbound tourism for the entire year. In some cases, Tour Operators gave their clients the opportunity of changing their previously booked holiday to some other destination in their program, with no additional payment even if their choice was more expensive. Many of their clients favoured this opportunity. The actions that tour operators are ready to take themselves in order to allow their clients to visit a destination at risk depend greatly on the interest in a particular country. The more important the destination is in their entire business program, the more attached to it they are (Nevenka, 2002). This was the case of some tour operators in Madeira, like $\mathrm{C} \& \mathrm{~N}-\mathrm{Thomas}$ Cook and TUI who, as shareholders in some hotels in the Island, were incentivised to try to return more quickly than to another one without such business interests. Today Madeira Island depends heavily on foreign tour operators, which control European tourism flows. These can significantly help the island to return more quickly to international markets. Although the largest European operators have returned, the accommodation capacities that they have taken are very small, and can hardly be compared with the period before the crisis.

Destination Marketing had to be constantly revised as the days went on. Efforts were directed at conveying the message that 'Madeira was safe'. Even without experience of such a situation, the government took some measures to try to minimize the effects of a negative message, by providing updates on victims, the weather, the reestablishment or rehabilitation of roads and telecommunications, and the relocation of bases through press releases throughout the day; offering online videos and photos of real testimonies of tourists who were at that time in the Island, conveying an image of safety and return to normal; and immediate invitation to politicians, opinion leaders and tour operators following the idea of 'come see for yourself'. These steps were then followed after some days or even weeks by a campaign using celebrities in small spots saying 'this year I'm going to Madeira' and the slogan 'Madeira - beautiful as ever', a strengthening of fam and press trips and the emergence of support groups on social network sites. However, while there was much discussion about post-crises strategies, the tourism industry particularly in the Atlantic Islands would require a recovery programme implemented during rather than after the crisis. All parties involved needed to extract and retain the learnings gained from the events of February and the recovery phase, as well as from crises that occurred in other destinations, to be able to develop the strategies and support systems to trigger such programmes immediately.

\section{Literature review}

The core resources and attractors of a destination are the primary elements of destination appeal and are the key motivators for visitation to a destination (Ritchie and Crouch, 2003). These factors are considered by the authors to fall into seven categories: physiography and climate, culture and history, market ties, mix of activities, special events, entertainment and tourism superstructure. However, the portrayal of places in news and popular culture can alter an area's image dramatically, even in a short period of time (Kim and Richardson, 2003). Indeed, to the casual observer exposed to the plethora of media that currently inform our daily lives, it appears that we live in an increasingly disaster prone world (Faulkner, 2001). Beirman (2003) provides a detailed analysis of several major natural and man-made crises and their impact on tourism. For tourism organizations and destinations, these crises have become increasingly important, because of the intense media coverage, and the preparedness of tourism consumers to avoid destinations they perceive as unsafe (Grainger and Crouch, 2006).

Perceived risk was seen as one of the costs of choice and since the concept of risk was introduced in economics in the 1920s (Knight, 1948), it has been successfully used in theories of decision making in economics, finance and the decision sciences (Dowling and Staelin, 1994). Since 2005, there has been renewed interest in the construct in tourism studies as statistics from around the world show that higher 
perceived risk is associated with decreased visitation (Sonmez et al., 1999). Indeed, Sonmez (1998) argued that destinations are evaluated according to their safety and risk factors with regard to terrorism and political problems. Hence, media coverage of disasters or crisis are of particular concern to destinations in which the negative event occurs, as well as to other destinations that may be connected in some way in the publics' mind to the crisis elsewhere, and even to destinations which may benefit from the adversity.

In consequence of this situation, many destinations are seen as dangerous and unsafe, places to avoid. Sometimes, the authorities of origin countries recommend to tourists to not travel to certain places where problems occur, aggravating the negative image that the tourists may have of these destinations.

When a crisis erupts, hotels, flights and other services reserved are cancelled within a matter of hours, along with scheduled sporting events, cultural events and conferences; tourists and investors disappear and ask questions about the future of the place. While a place's positive image and reputation are built up over a period of years, it might take only a few moments to reach a state of crisis that could seriously damage the place's image, its tourism industry and the entire economy (Avraham and Ketter, 2008b).

Several studies analyze crisis dynamics and processes and propose planning and management models. Crisis can evolve at great speed in a chaotic manner, but are not always identifiable in advance. Recommendations on how to deal with these problems may be too general or too attached to one or to a particular case.

The underlying problem of predicting the unpredictable means that managers are not always fully prepared and must respond intuitively to unfamiliar and confused situations as they unfold in a random manner. Handling crisis is an especial challenge for those at work in tourism industry, which involves the movement and accommodation of people. Costumers face personal inconvenience when things go wrong and their physical well-being and lives, as well as those of staff, may be threatened in the most severe conditions of crisis (Henderson, 2005).

Avraham and Ketter (2008a) propose a holistic multi-step model to restore a place's positive image. The first step should be the preliminary analyses of the crisis, audience and place characteristics (CAP analysis), which include examining the crisis, the place where the crisis occurred and singling out the target audience for whom the place tries to alter its image. After that, place marketers should define the campaign's goals and the timing of the launch of the campaign. Next is the stage of choosing the most suitable marketing strategy or mix strategies, as indicated by the preliminary analysis and the campaign objectives and timing. The choice can be among three groups of media strategies - those that focus on the source of the message, those that focus on the message itself and those that focus on the target audience (SAM strategies: source, audience and message). The authors analyse also the use of SAM strategies adopted by various places in order to combat their unsafe images. Source strategies consist in trying to bypass the source of negative information by using two major strategies: 'Come see for yourself' that the place is safe; and using celebrities as an alternative source of information. Message Strategies, rather than looking at the source, focuses on the message itself, following different ideas:

1. Ignoring or limiting the crisis, pretending that nothing bad has happened or that the damage is minor;

2. 'Fencing off' the crisis, restricting the problems to certain areas;

3. Multiple facets and softening the "hard" image, adding new positive elements to their image;

4. Reducing the scale of the crisis, some places choose to acknowledge a crisis while reducing its scale to minimize the damage to their image;

5. Tackling the reasons for the placés lack of safety, addressing and correcting the reasons that caused the negative image in the first place;

6. Hosting spotlight sport and cultural events, allowing the host place to promote certain chosen images that can be used to improve an unsafe image, and making available positive alternatives to draw the media away from the negative portrayal of a place.;

7. Promoting the placés 'safe' image by using films, helping to promote a place following the idea that 'if actors are able to live and shoot movies in the place peacefully, it will bolster the efforts to promote a destination';

8. Delivering a counter-message to the unsafe image, by adopting advertising campaigns with opposite images to their current one;

9. Spinning the 'unsafe' image into assets, recognizing a negative factor responsible for the unsafe image and spin it into a positive trait;

10. Ridicule the stereotype of; 'unsafe' place, showing how ridiculous it is and thereby nullify it.

Finally, the Audience Strategies that can be divided into two:

1. Patriotism and Nationalism, addressing residents directly and asking them to demonstrate those feelings and 
2. Changing the target audience, as usually the place image is formed by different actors whose impact could be negative for one target audience and positive for another.

The industry within the country can manage the crisis efficiently only by being prepared to take some actions in advance. Planning is an essential element of control. Without it, an organization is at the mercy of events (Barton, 1994). The recovery of this industry from a crisis is far more complicated than for others. As proven in practice and stressed by Sonmez et al. (1999:15), although tourism is quite adept at using established marketing principles, setbacks due to negative occurrences call for something more than traditional efforts. The industry must conduct recovery marketing that is integrated fully with crisis management activities. Its complexity requires a proactive role from all tourism officials in the public and private management of marketing activities.

Very strong partnership and coordinated work among the government, national tourism organizations, foreign tour operators, local travel organizers and local hospitality officials are essential. Each needs to participate to an important degree in order to secure the fulfillment of several important actions (Nevenka, 2002). These include successful rebuilding of the destination image, overcoming any adverse publicity resulting from the crisis, short-term restoration and long-term reconstruction of the damaged tourism facilities and infrastructure and effective management of media coverage (Drabek, 2000).

\section{Conclusion}

In a world of changing economic and social politics, crises have become familiar problems, even in developed countries like the United States, Spain or the United Kingdom, which suffered serious problems in the last decade. In this era of electronic technologies with its capacity of spreading news and images instantly, tourist destinations can be deserted within a few hours. The Madeira floods struck without warning and gave rise to a crisis in the local tourism industry. The projection of the sudden tragic event in the media had an immediate negative effect on the tourism industry, with its accompanying economic problems, the loss of appeal as a destination for tourists, new investors, traders and even local residents who no longer saw the attraction of their region. Prices of tourism-related products and services declined in response to the reduced demand and revenues are not covering costs. As a result, there have been cutbacks in employment and a short-term drop in quality.
Every destination that is considered to have a positive image spends millions of euros in sophisticated marketing campaigns with the aim of creating strong, attractive brands. Such spend is essential given the growing competition between countries and tourist destinations for new investors, tourists and more media coverage. Also, the larger the investment, the greater the need to factor in counter strategies to deal with any event could adversely influence that image. Policy makers and those responsible for marketing destinations have to constantly retain on their agendas the ways of preventing the negative fallout of disaster events and the response strategies to manage the ongoing stability of the tourism industry and its quick recovery. There has to be an intimate familiarity with all aspects and dimensions of the Madeira case and others, for decision makers to be able to locate their management decisions within the precincts of past experience, from there to further refine their abilities, and thereby create best practice over time for the management of crises on the Island, and in anticipation of future events. To achieve these objectives, it is essential that tourism stability programmes and projects be in place in time for the industry and political society to be in immediate control of the next crisis, instead of waiting to pick up the pieces afterwards because of inadequate plans. It should be within the mandate of the industry leaders to create as their legacy strategies and techniques that promote the continued health and vibrancy of the tourism market in Madeira.

\section{References}

Avraham E and Ketter E (2008a) Media Strategies for Marketing Places in Crisis: Improving the Image of Cities, Countries and Tourist Destinations. Oxford, UK: Butterworth Heinemann.

Avraham E and Ketter E (2008b) Will we be safe there? Analysing strategies for altering unsafe place images. Place Branding and Public Diplomacy, Palgrave Macmillan Ltd, 4: 196-204, (August 2008), doi:10.1057/pb.2008.

Barros CP and Machado LP (2010) The length of stay in tourism. Annals of Tourism Research 37: 692-706.

Barton L (1994) Crisis management: Preparing for and managing disaster. The Cornell Hotel and Restaurant Administration Quarterly 35(3): 59-65.

Dowling GR and Staelin R (1994) A model of perceived risk and intended risk-handling activity. The fournal of Consumer Research 21(1): 119-134.

Drabek T (1994) Disaster Evacuation and the Tourist Industry. Boulder CO: Institute of Behavioral Science, University of Colorado.

Faulkner B (2001) Towards a framework for tourism disaster management. Tourism Management 22: 135-147.

Grainger J and Crouch Geoffrey I (2006) Reconceptualising Destination Image Using Perceived Risk. Hellenic Open University, Crete, June 15-18, 2006.

Hall M, Dallen JT and Duval DT (2004) Safety and Security in Tourism: Relationships, Management, and Marketing. London: Hawthorne Hospitality Press. 
Henderson JC (2005) Responding to natural disasters: Managing a hotel in the aftermath of the Indian Ocean Tsunami. Tourism and Hospitality Research 6: 1; ABI/INFORM Global.

Kim H and Richardson SL (2003) Motion Picture Impacts on Destination Images. Annals of Tourism Research 30(1): 216-237.

Knight F (1948) Risk, Uncertainty and Profit. Boston, MA: Houghton Mifflin Company.

Nevenka Cavlek (2002) Tour operators and destination safety. Annals of Tourism Research 29(2): 478-496.

Oliveira P and Pereira PT (2008) Who values what in a tourism destination? The case of Madeira Island. Tourism Economics 14(1): 155-168.

\section{Author Biography}

Luiz Pinto Machado was born in Lisbon, in 1962, and hold a degree in Tourism Business Management, Master in Strategic Management and Planning of Tourism Madeira University and Doctorate in Economics from the Technical University of Lisbon (ISEG). Starting his professional career in tourism in
Richardson B (1994) Crisis management and management strategy. Time to "Loop the Loop"?". Disaster Prevention and Management 3(3): 59-80.

Ritchie JRB and Crouch GI (2003) The competitive destination: $A$ sustainable tourism perspective. Cambridge, MA: CABI.

Sonmez SF (1998) Tourism, terrorism, and political instability. Annals of Tourism Research 25: 416-456.

Sonmez SF, Apostolopoulos Y and Tarlow P (1999) Tourism in Crisis: Managing the Effects of Terrorism. Fournal of Travel Research 38(1): 3-9.

1978 , he is today an entrepreneur in tourism. He teaches in several schools, especially the School of Hospitality and Tourism Madeira where he has been teaching since 1993. He has collaborated in several projects of planning and strategy and published books and several scientific articles on Tourism. 